\title{
A Universal Fluorinated Polymer Acceptor Enables All-Polymer Solar Cells with Efficiency Over 15\%
}

Feng Peng,,+ Kang An,", Wenkai Zhong, ' Zhenye Li, ' Lei Ying, *, + Ning Li, , Zhenqiang Huang, ${ }^{\dagger}$ Chunguang Zhu, ${ }^{\dagger}$ Baobing Fan, ${ }^{\dagger}$ Fei Huang, ${ }^{\dagger}$ and Yong Cao ${ }^{\dagger}$

Institute of Polymer Optoelectronic Materials and Devices, State Key Laboratory of Luminescent Materials and Devices, South China University of Technology, Guangzhou, 510640, P. R. China

Institute of Materials for Electronics and Energy Technology (i-MEET), FriedrichAlexander-Universität Erlangen-Nürnberg, Martensstr. 7, 91058 Erlangen, Germany

\section{Corresponding Author}

*msleiying@scut.edu.cn 


\section{Experimental section}

\section{Materials}

PBDB-T, PM6, 2,5-bis(trimethylstannyl)thiophene, 1-bromo-2-fluoro-4,5dimethylbenzene and other reagents and solvents were purchased from Dongguan Alda New Materials Technology Co. Ltd, and used directly without further purification. Compound 5, PTzBI-oF and PY5T were synthesized according to the previous reports..$^{1,2}$

\section{Synthesis of Compound 1}

1-Bromo-2-fluoro-4,5-dimethylbenzene (5.00 g, $24.63 \mathrm{mmol})$, potassium hydroxide (1.97 g, $49.26 \mathrm{mmol})$ and deionized water $(150 \mathrm{~mL})$ were heated to reflux. Then potassium permanganate $(15.57 \mathrm{~g}, 98.52 \mathrm{mmol})$ was carefully added into the reaction and the mixture was kept reflux overnight. After cooling and filtering, the filtrate was extracted with ethyl acetate $(100 \mathrm{~mL})$ for three times. Compound $\mathbf{1}(6.18 \mathrm{~g}, 23.50 \mathrm{mmol}$, yield $=95 \%$ ) was obtained after evaporating the organic phase as a white solid. ${ }^{1} \mathrm{H}$ NMR (400 MHz, DMSO-d $\left.{ }_{6}\right) \delta(\mathrm{ppm}): 13.77$ (s, 2H), 8.06 (d, $\left.J=6.7 \mathrm{~Hz}, 1 \mathrm{H}\right), 7.69$ (d, $J=8.9 \mathrm{~Hz}, 1 \mathrm{H}) ;{ }^{13} \mathrm{C}$ NMR (101 MHz, DMSO-d 6 ) $\delta(\mathrm{ppm}): 167.72,167.19,161.42$, $158.93,136.20,136.13,135.19,131.26,117.94,117.69,111.55,111.34$.

\section{Synthesis of compound 2}

Compound $1(6.00 \mathrm{~g}, 22.81 \mathrm{mmol})$ and acetic anhydride $(50 \mathrm{~mL})$ were heated to reflux for $4 \mathrm{~h}$. The reaction solution was evaporated to afford compound $2(5.30 \mathrm{~g}, 21.63 \mathrm{mmol}$, yield $=92 \%)$ as a white solid. ${ }^{1} \mathrm{H}$ NMR $\left(400 \mathrm{MHz}, \mathrm{DMSO}-\mathrm{d}_{6}\right) \delta(\mathrm{ppm}): 8.05(\mathrm{~d}, J=6.7$ $\mathrm{Hz}, 1 \mathrm{H}), 7.68(\mathrm{~d}, J=8.9 \mathrm{~Hz}, 1 \mathrm{H}) ;{ }^{13} \mathrm{C}$ NMR $\left(101 \mathrm{MHz}, \mathrm{DMSO}-\mathrm{d}_{6}\right) \delta(\mathrm{ppm}): 166.81$, 
$166.28,160.24,158.25,135.18,135.12,134.11,130.21,116.87,116.67,110.60$ 110.43 .

\section{Synthesis of compound 3}

Compound $2(5.00 \mathrm{~g}, 20.40 \mathrm{mmol})$, tert-butyl acetoacetate $(3.55 \mathrm{~g}, 22.44 \mathrm{mmol})$ and trimethylamine $(5 \mathrm{~mL})$ were added into acetic anhydride $(60 \mathrm{~mL})$ and stirred at room temperature overnight. Then the reaction solution was carefully poured into $300 \mathrm{~mL}$ hydrochloric acid ice solution $(1 \mathrm{M})$ and then heated to $80{ }^{\circ} \mathrm{C}$ for $2 \mathrm{~h}$. After cooling, compound $3(4.26 \mathrm{~g}, 17.54 \mathrm{mmol}$, yield $=86 \%)$ was gained by filtering as a gray solid. ${ }^{1} \mathrm{H}$ NMR (400 MHz, DMSO-d $\left.{ }_{6}\right) \delta(\mathrm{ppm}): 8.23(\mathrm{~d}, J=5.9 \mathrm{~Hz}, 1 \mathrm{H}), 7.64(\mathrm{~d}, J=6.6 \mathrm{~Hz}$, 1H), $3.27(\mathrm{~s}, 2 \mathrm{H}) .{ }^{13} \mathrm{C} \mathrm{NMR}\left(126 \mathrm{MHz}, \mathrm{CDCl}_{3}\right) \delta(\mathrm{ppm}): 195.13,194.34,173.32$, $144.34,139.92,137.46,129.53,110.39,44.94$

\section{Synthesis of compound 4 (4a and $4 b)$}

Compound 3 (4.00 g, $16.46 \mathrm{mmol})$, malononitrile (1.30 g, $19.75 \mathrm{mmol})$, sodium acetate (1.62 g, $19.75 \mathrm{mmol})$ and ethanol $(100 \mathrm{~mL})$ were stirred at room temperature overnight. After acidizing to $\mathrm{pH} \approx 1$ by dilute hydrochloric acid, the mixture was extracted with ethyl acetate $(200 \mathrm{~mL})$ and washed by sodium chloride aqueous solution. The organic phase was evaporated. The crude product was purified by column chromatography with petroleum ether/dichloromethane (1:2) as eluent to give compound 4 (blend of $4 \mathrm{a}$ and 4b) $(4.08 \mathrm{~g}, 14.02 \mathrm{mmol}$, yield $=85 \%)$ as a caesious powder. ${ }^{1} \mathrm{H}$ NMR $(400 \mathrm{MHz}$, $\left.\mathrm{CDCl}_{3}\right) \delta(\mathrm{ppm}): 8.89(\mathrm{~d}, J=5.6 \mathrm{~Hz}, 0.47 \mathrm{H}), 8.34(\mathrm{~d}, J=7.9 \mathrm{~Hz}, 0.53 \mathrm{H}), 8.21(\mathrm{~d}, J=$ $6.3 \mathrm{~Hz}, 0.53 \mathrm{H}), 7.65(\mathrm{~d}, J=6.4 \mathrm{~Hz}, 0.47 \mathrm{H}), 3.76(\mathrm{~s}, 2 \mathrm{H}) ;{ }^{13} \mathrm{C} \mathrm{NMR}\left(126 \mathrm{MHz}, \mathrm{CDCl}_{3}\right)$ $\delta(\mathrm{ppm}): 192.63,191.94,164.66,163.99,163.43,162.06,142.92,141.97,138.97$, 
$137.28,131.60,130.39,119.87,119.64,113.28,113.01,111.76,111.62,111.55,80.81$ $79.95,43.41,43.17$.

\section{Synthesis of Y5-F-Br}

Compound 4 (1.18 g, $4.06 \mathrm{mmol})$, compound 5 (2.00 g, $1.35 \mathrm{mmol})$, pyridine (6 mL), and chloroform $(200 \mathrm{~mL})$ were heated to reflux for $12 \mathrm{~h}$. After cooling, the reaction solution was poured into methanol $(200 \mathrm{~mL})$ and then filtered. The residue was further purified by column chromatography with petroleum ether/dichloromethane (8:1) as eluent to give Y5-F-Br $(2.36 \mathrm{~g}, 1.17 \mathrm{mmol}$, yield $=86 \%)$ a dark blue powder. ${ }^{1} \mathrm{H}$ NMR $\left(400 \mathrm{MHz}, \mathrm{CDCl}_{3}\right) \delta(\mathrm{ppm}): 9.18(\mathrm{~s}, 2 \mathrm{H}), 8.95(\mathrm{~d}, J=5.6 \mathrm{~Hz}, 0.65 \mathrm{H}), 8.45(\mathrm{~d}, J=8.6$ $\mathrm{Hz}, 1.35 \mathrm{H}), 8.11(\mathrm{~d}, J=6.4 \mathrm{~Hz}, 1.35 \mathrm{H}), 7.60(\mathrm{~d}, J=6.3 \mathrm{~Hz}, 0.65 \mathrm{H}), 4.76(\mathrm{~d}, J=7.5$ $\mathrm{Hz}, 4 \mathrm{H}), 3.23(\mathrm{t}, J=7.6 \mathrm{~Hz}, 4 \mathrm{H}), 2.10(\mathrm{~d}, \mathrm{~J}=4.5 \mathrm{~Hz}, 2 \mathrm{H}), 1.93-1.82(\mathrm{~m}, 4 \mathrm{H}), 1.53$ $(\mathrm{dt}, \mathrm{J}=15.0,7.3 \mathrm{~Hz}, 4 \mathrm{H}), 1.42-0.73(\mathrm{~m}, 126 \mathrm{H}) ;{ }^{13} \mathrm{C} \mathrm{NMR}\left(126 \mathrm{MHz}, \mathrm{CDCl}_{3}\right) \delta(\mathrm{ppm})$ : $186.33,185.97,163.88,163.71,161.83,161.64,158.89,158.66,154.13,154.09$, $147.63,145.39,140.87,140.79,138.74,138.68,137.85,136.58,136.42,136.32$, $135.71,135.63,134.41,133.88,133.86,133.69,133.61,131.25,130.96,128.96$, $120.13,119.97,117.40,117.22,116.97,116.79,115.16,114.75,114.68,113.78$, $113.54,113.32,111.09,110.89,68.96,55.81,39.3,32.10,32.07,31.40,30.69,30.04$, $30.01,29.92,29.85,29.82,29.78,29.71,29.69,29.61,29.56,29.51,29.49,25.72,22.86$, 22.84, 14.27; ${ }^{19} \mathrm{~F} \mathrm{NMR}\left(471 \mathrm{MHz}, \mathrm{CDCl}_{3}\right) \delta(\mathrm{ppm})$ : -93.22 (s, 0.67F), -94.26 (s, 0.33F).

\section{Synthesis of PFA1}

Y5-F-Br (202.3 mg, $0.1 \mathrm{mmol}), 2$,5-bis(trimethylstannyl)thiophene (41.0 mg, $0.1 \mathrm{mmol})$ and toluene $(2 \mathrm{~mL})$ were added into a sealed tube. After bubbling with $\mathrm{N}_{2}$ for $15 \mathrm{~min}$., 
tris(dibenzylideneacetone)dipalladium $(2 \mathrm{mg})$ and tris(2-methylphenyl)phosphine (4 $\mathrm{mg}$ ) were added into the solution. The mixture was sealed and then allowed to react at $130^{\circ} \mathrm{C}$ for $24 \mathrm{~h}$. After cooling to room temperature, the reaction solution was dropwise added into $150 \mathrm{~mL}$ methanol and the precipitate was filtered out. The crude polymer was washed with methanol, acetone and n-hexane in a Soxhlet apparatus, then redissolved in chloroform. The solution was concentrated to $15 \mathrm{~mL}$ and reprecipitated in $150 \mathrm{~mL}$ methanol. The anticipated PFA1 was obtained by filtration and drying under vacuum as a dark solid (yield $=91 \%$ ).

\section{Measurements}

${ }^{1} \mathrm{H}$ NMR, ${ }^{13} \mathrm{C}$ NMR and ${ }^{19} \mathrm{~F}$ NMR spectra were recorded on a Bruker DRX 400 spectrometer. Molecular weights of the polymers were measured on an Acquity Advanced Polymer Chromatography (Waters) with high temperature chromatograph, using $1,2,4$-trichlorobenzene as the mobile phase at $150^{\circ} \mathrm{C}$. UV-vis absorption spectra and photoluminescence (PL) spectra were measured on a Shimadzu UV-3600 spectrometer and a HORIBA scientific fluoromax-4 spectro-fluorometer, respectively. The polymer films used for absorption coefficient measurement were spin-coated from chloroform solution (with concentration of about $6 \mathrm{mg} \mathrm{mL}^{-1}$ ) onto quartz plate substrate (with the thickness of $\sim 100 \mathrm{~nm}$ ), then annealing at $100^{\circ} \mathrm{C}$ for $10 \mathrm{~min}$. The measurement of absorption coefficient of polymers in chloroform solution was carried out by dissolving polymer in chloroform with concentration of about $1.0 \times 10^{-5} \mathrm{~g} \mathrm{~mL}^{-1}$. After subtracting the signal of blank sample, UV-vis absorption intensity was measured on a 
Shimadzu UV-3600 spectrometer. Cyclic voltammetry (CV) measurements were performed on a CHI800C electrochemical workstation equipped with a glass carbon working electrode, a saturated calomel reference electrode and a Pt sheet counter electrode, using $\mathrm{Bu}_{4} \mathrm{NPF}_{6}$ acetonitrile solution $(0.1 \mathrm{M})$ as the electrolyte. The ferrocene/ferrocenium redox couple $\left(\mathrm{Fc} / \mathrm{Fc}^{+}\right)$was used as the external standard and the redox potential of $\mathrm{Fc} / \mathrm{Fc}^{+}\left(\mathrm{E}_{\mathrm{Fc} / \mathrm{Fc}}{ }^{+}\right)$was determined to be $0.38 \mathrm{~V}$. With regard to energy level of the ferrocene reference (4.8 eV to vacuum), the highest occupied molecular orbital energy level $\left(\mathrm{E}_{\mathrm{HOMO}}\right)$ and the lowest unoccupied molecular orbital energy level $\left(\mathrm{E}_{\mathrm{LUMO}}\right)$ are calculated according to the equations of $\mathrm{E}_{\mathrm{HOMO}}=-\mathrm{e}\left(\mathrm{E}_{\mathrm{Ox}}+4.8-\mathrm{E}_{\mathrm{Fc} / \mathrm{Fc}}{ }^{+}\right)$ and $\mathrm{E}_{\mathrm{LUMO}}=-\mathrm{e}\left(\mathrm{E}_{\mathrm{red}}+4.8-\mathrm{E}_{\mathrm{Fc} / \mathrm{Fc}}^{+}\right)$, respectively, where $\mathrm{E}_{\mathrm{ox}}$ and $\mathrm{E}_{\mathrm{red}}$ are onset of the first oxidation and reduction potentials. Atomic force microscopy (AFM) images were recorded on a Bruker Multimode 8 microscope in the tapping mode. Transmission electron microscopy (TEM) images were obtained using a JEM-2100F instrument. Grazing incidence wide-angle X-ray scattering (GIWAXS) measurements was performed on a Xenocs Xeuss 2.0 system with an Excillum MetalJet-D2 X-ray source operated at $70.0 \mathrm{kV}, 2.8570 \mathrm{~mA}$, and a wavelength of $1.341 \AA$. The sample to detector distance was $\sim 223 \mathrm{~mm}$ and the incidence angle was set at $0.20^{\circ}$. Scattering images were recorded using a DECTRIS PILATUS3 R 1M area detector with a pixel size of 0.172 $\mathrm{mm}$ by $0.172 \mathrm{~mm}$. Samples were prepared by spin-coating the films on PEDOT:PSS/silicon wafer substrates.

\section{Device fabrication and characterization}


Organic solar cells with a conventional structure of ITO/PEDOT:PSS/active layer/PFN-Br/Ag were fabricated according to a well-established operating procedures. Patterned indium tin oxide (ITO) glass substrates were cleaned with acetone, isopropanol, detergent, deionized water and isopropanol in succession. After dried in vacuum at $80{ }^{\circ} \mathrm{C}$ overnight, ITO substrates underwent 2 min oxygen plasma treatment. A $40 \mathrm{~nm}$ thick PEDOT:PSS layer was spin-coated on the ITO substrates and then baked at $150{ }^{\circ} \mathrm{C}$ for $20 \mathrm{~min}$. The PTzBI-oF:PY5T and PTzBI-oF:PFA1 blends with the ratio of 1:1 were dissolved in chloroform (CF) or chloroform containing $0.3 \sim 0.7 \% \quad 1$ chloronaphthalene $(\mathrm{CN})$, and the concentration of polymers were $6 \mathrm{mg} \mathrm{mL}^{-1}$. The blend films were formed by spin-coating atop PEDOT:PSS layer at $700 \mathrm{rpm}$ for $20 \mathrm{~s}$ and annealed at $100{ }^{\circ} \mathrm{C}$ for $10 \mathrm{~min}$. The film thicknesses of photoactive layers were maintained at about $100 \mathrm{~nm}$. Then, $5 \mathrm{~nm}$ of PFN-Br was spin-coated from methanol:ethanol mixed solution as the cathode interface. The thicknesses of the organic films were measured by profilometry with a Tencor Alfa-Step 500. At last, 100 $\mathrm{nm}$ of argentum (Ag) layer (thicknesses monitored by an STM-100/MF-Sycon quartz crystal) was thermally deposited onto the organic layer through a shadow mask under a vacuum of $1 \times 10^{-6} \mathrm{~Pa}$. The effective area of the devices was $0.04 \mathrm{~cm}^{2}$.

The current density-voltage $(\mathrm{J}-\mathrm{V})$ characteristics were measured under a computer controlled Keithley 2400 sourcemeter under 1 sun, AM 1.5G solar simulator (Taiwan, Enlitech SS-F5). The EQE spectra was recorded by a Enlitech QE-R3011 EQE measurement system. 


\section{Single-carrier devices fabrication and characterization}

The hole-only and electron-only devices were fabricated with the structures of ITO/PEDOT:PSS/active layer $/ \mathrm{M}_{\mathrm{O}} \mathrm{O}_{3} / \mathrm{Ag}$ and ITO/ZnO/active layer/PFN-Br/Al, respectively. For the hole-only device, $10 \mathrm{~nm}$ of $\mathrm{M}_{\mathrm{O}} \mathrm{O}_{3}$ was vacuum-deposited on the active layer as the cathode. For the electron-only device, $40 \mathrm{~nm}$ of $\mathrm{ZnO}$ layer was spincoated from the $\mathrm{ZnO}$ sol-gel. The other layers were prepared similar to the corresponding solar cells.

The mobility $\mu$ was determined by fitting the dark current to the model of a single carrier SCLC, which is described by the following equation:

$$
\mathrm{J}=(9 / 8) \varepsilon^{0} \varepsilon^{r} \mu V^{2} / d^{3},
$$

where $J$ is the current density, $\varepsilon_{0}$ is the free-space permittivity, $\varepsilon_{r}$ is the relative permittivity of the material, $V$ is the effective voltage $V-V_{b i}$ and $d$ is the thickness of the active layer. The charge (hole or electron) mobilities are calculated from the y-intercept of the $J-V$ curves. 


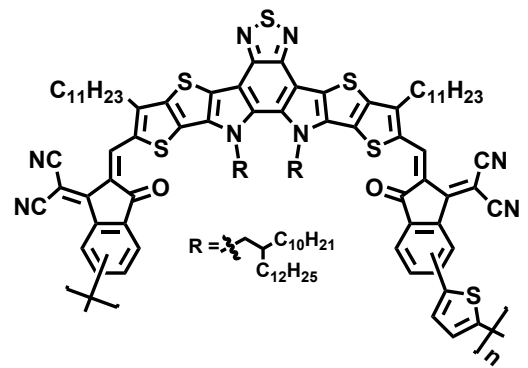

PY5T

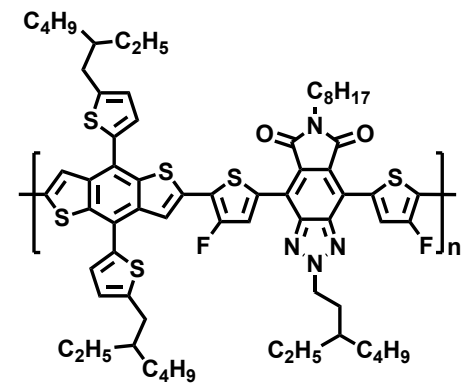

PTzBI-oF

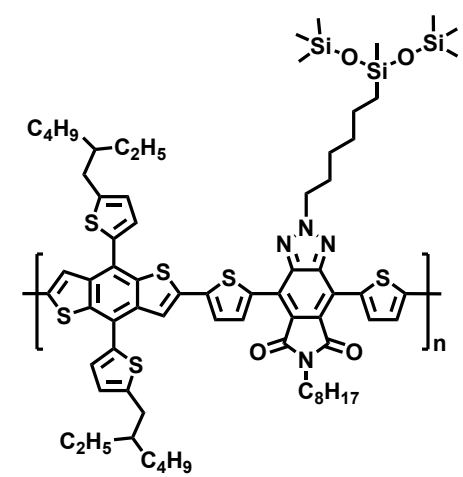

PTzBI-Si

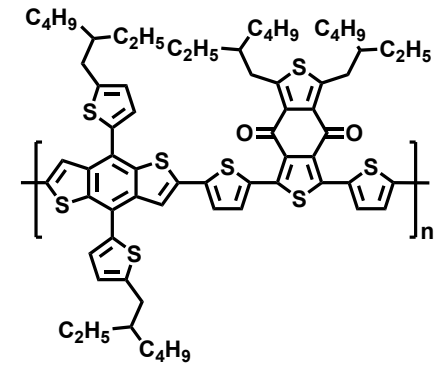

PBDB-T

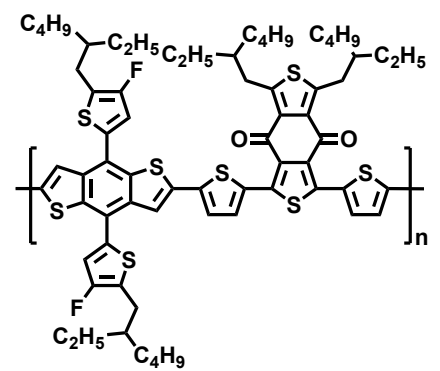

PM6

Figure S1. Chemical structures of PY5T, PTzBI-oF, PTzBI-Si, PBDB-T and PM6.

(a)

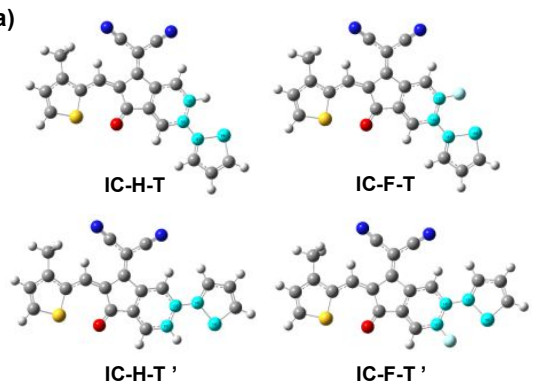

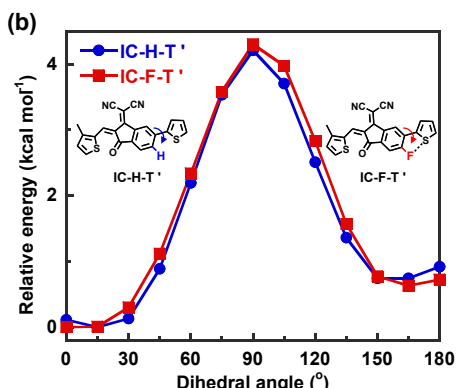

Figure S2. (a) Optimized geometry for model fragments of PY5T and PFA1. (b) PES scan of model compounds IC-H-T' and IC-F-T' for the other conformation of PY5T and PFA1, respectively. 
(a)

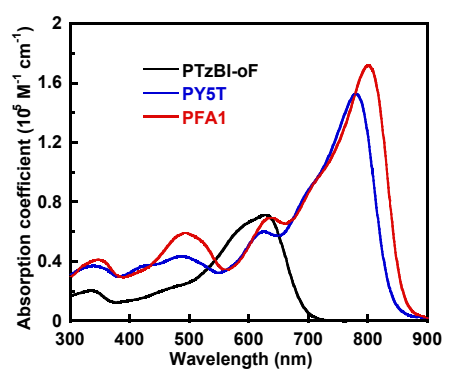

(b)

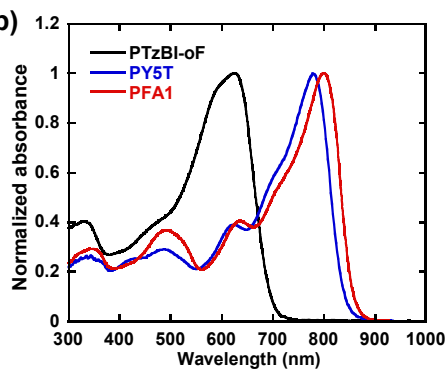

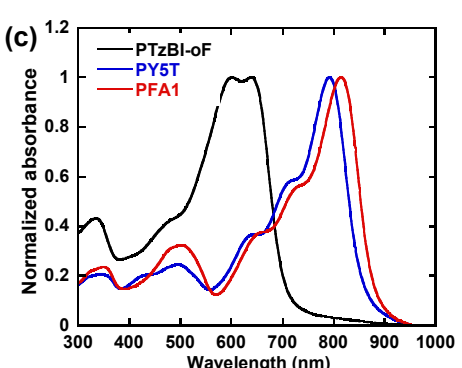

Figure S3. (a) Absorption coefficient of polymers in chloroform with concentration of $1.0 \times 10^{-5} \mathrm{~g} \mathrm{~mL}^{-1}$. The normalized UV-vis absorption spectra of polymers (b) in dilute chloroform solution and (c) thin film.

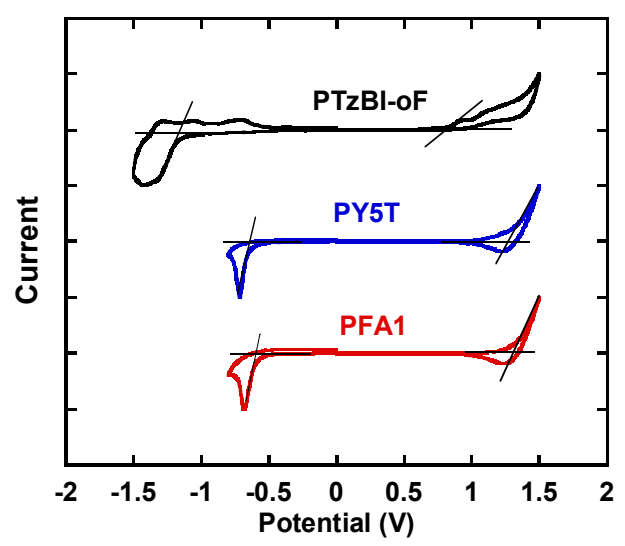

Figure S4. CV curves of polymers (versus saturated calomel electrode, SCE). 

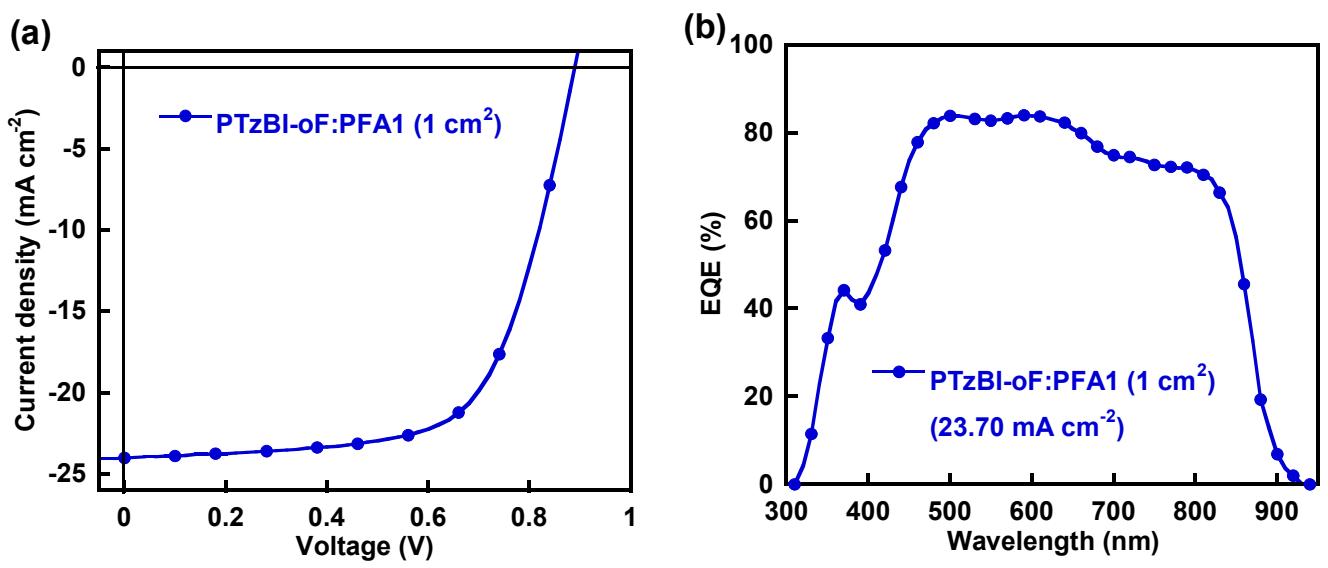

Figure S5. (a) $J-V$ characteristics and (b) EQE spectra of large area all-PSC based on PTzBI-oF:PFA1 with an effective area of $1 \mathrm{~cm}^{2}$. The device structure is ITO/PEDOT:PSS/PTzBI-oF:Y5-F-Br/PFN-Br/Ag. Inset is the photo of $1 \mathrm{~cm}^{2}$ cell on an ITO layout.
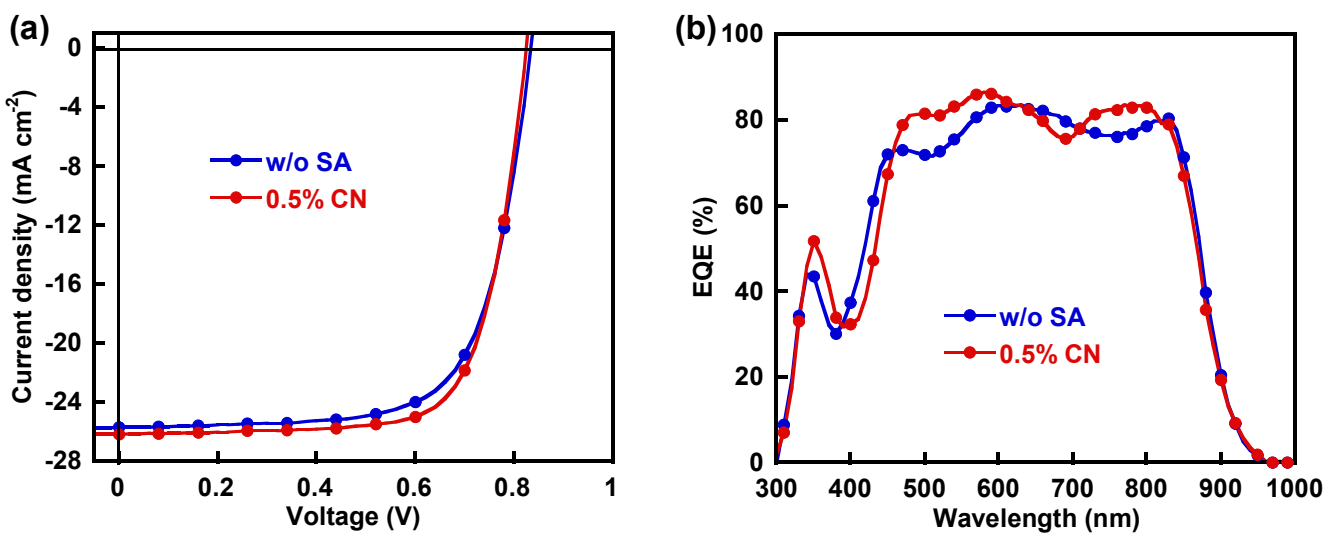

Figure S6. (a) $J-V$ characteristics and (b) EQE spectra of devices based on PTzBIoF:Y5-F-Br with or without solvent additive. The device structure is ITO/PEDOT:PSS/PTzBI-oF:Y5-F-Br/PFN-Br/Ag. The effective area of the devices is $0.04 \mathrm{~cm}^{2}$. 

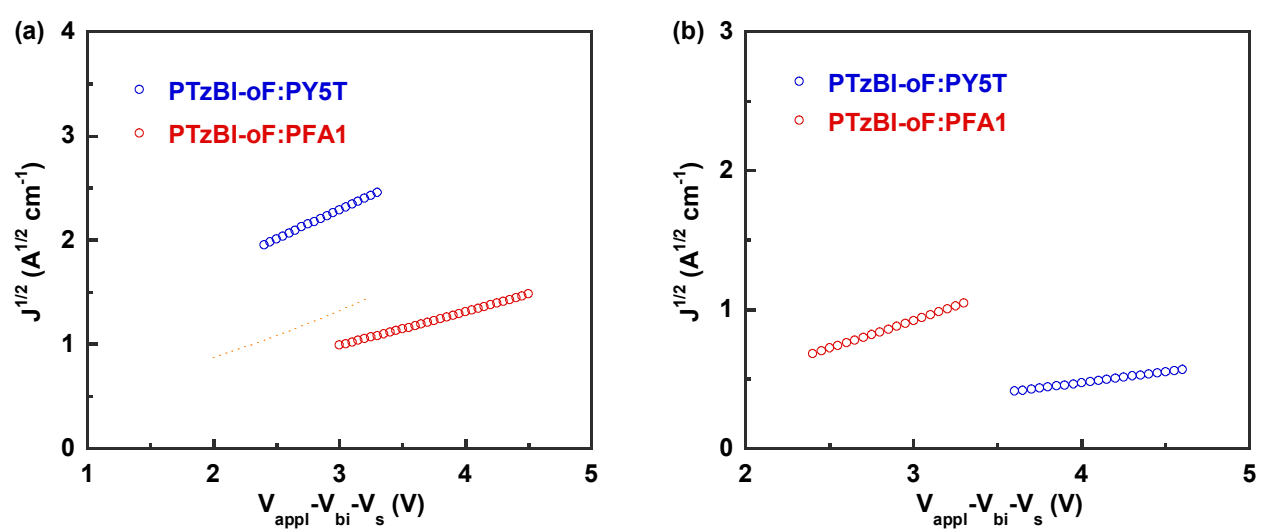

Figure S7. Dark $J^{1 / 2}-V$ characteristics for (a) hole-only and (b) electron-only devices based on blend films with the structure of ITO/PEDOT:PSS/active layer/ $\mathrm{M}_{\mathrm{O}} \mathrm{O}_{3} / \mathrm{Ag}$ and $\mathrm{ITO} / \mathrm{ZnO} /$ active layer/PFN-Br/Al
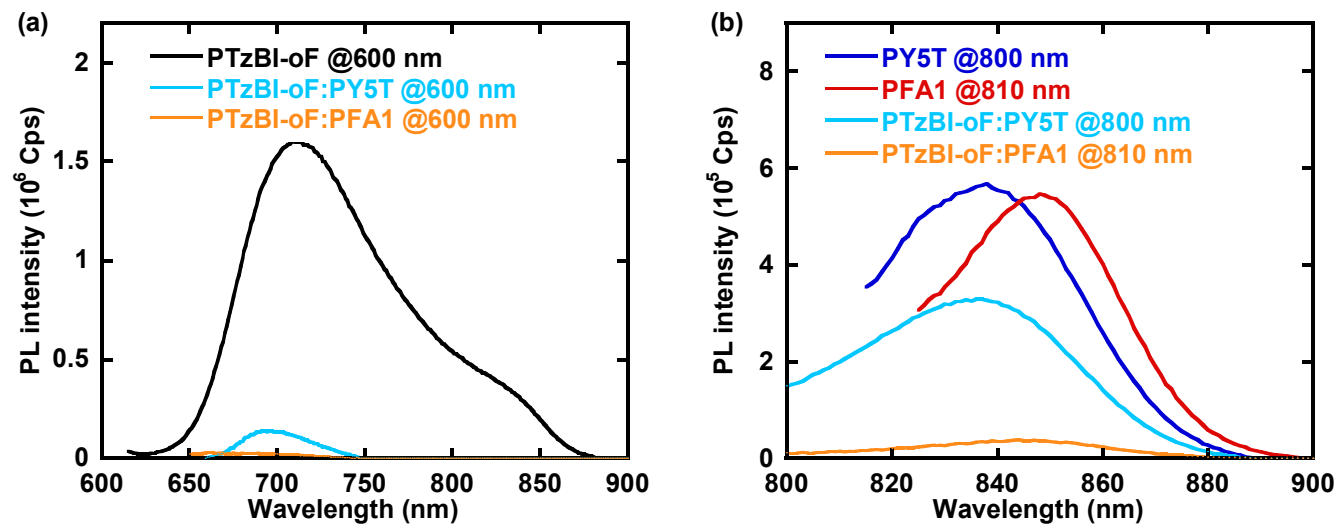

Figure S8. PL responses for polymer acceptors and corresponding blends excited at (a) $600 \mathrm{~nm}$ and (b) around $800 \mathrm{~nm}$. 
(a)

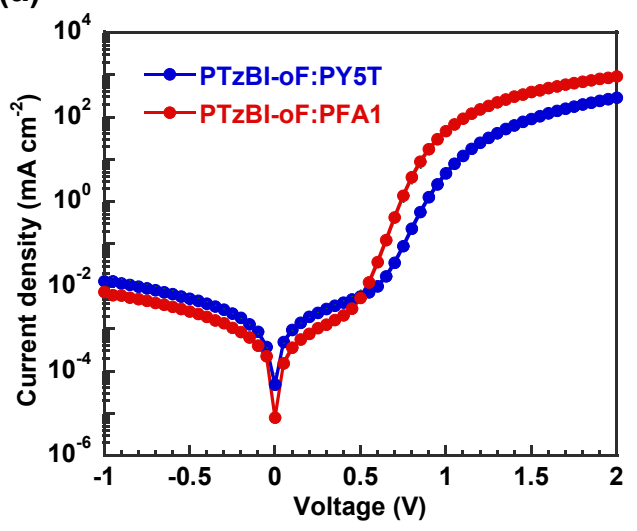

(b)

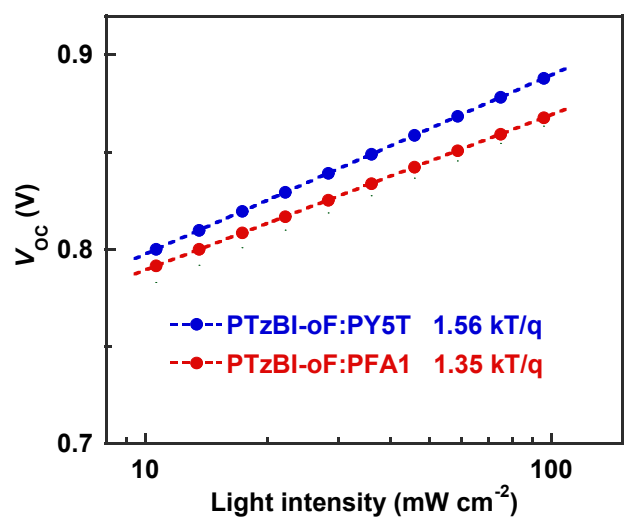

Figure S9. (a) Dark $J-V$ characteristics and (b) $V_{\mathrm{OC}}$ versus $P_{\text {light }}$ characteristics for allPSCs based on PTzBI-oF:PY5T and PTzBI-oF:PFA1.
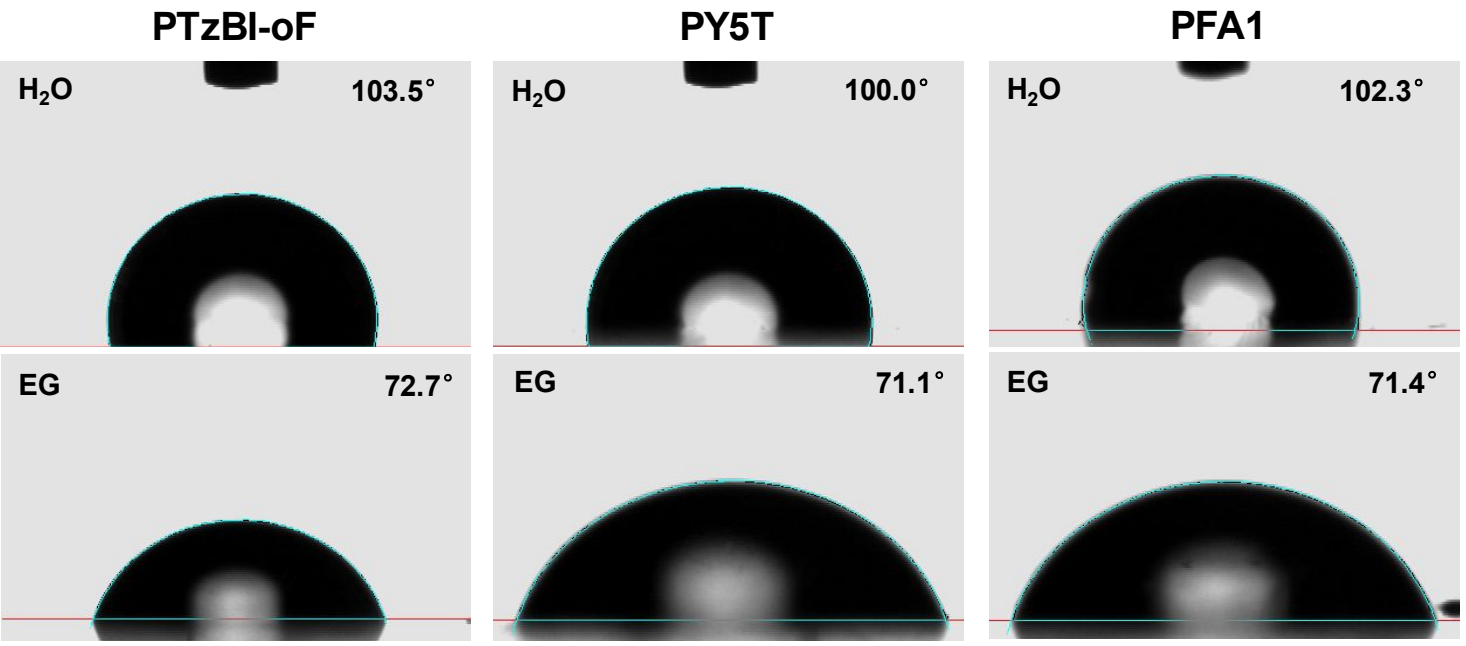

Figure S10. Contact angle measurements of the pristine PTzBI-oF, PY5T and PFA1

films cast from chloroform solution. The measurements are carried out by using deionized water $\left(\mathrm{H}_{2} \mathrm{O}\right)$ and ethylene glycol (EG) as the wetting liquid. 

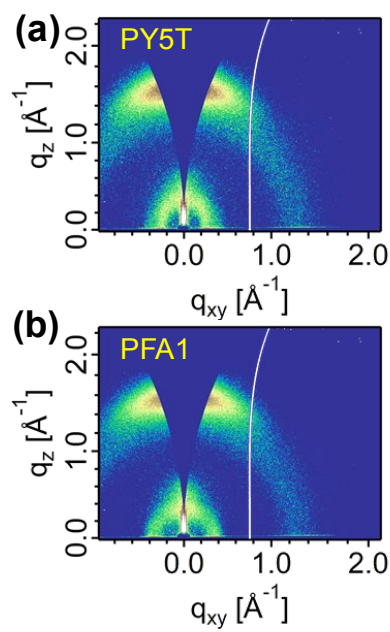
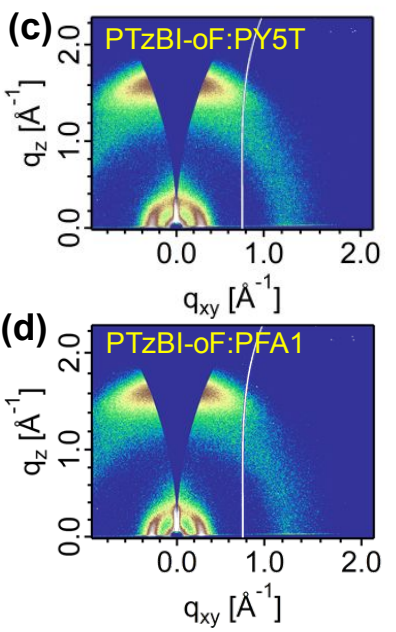

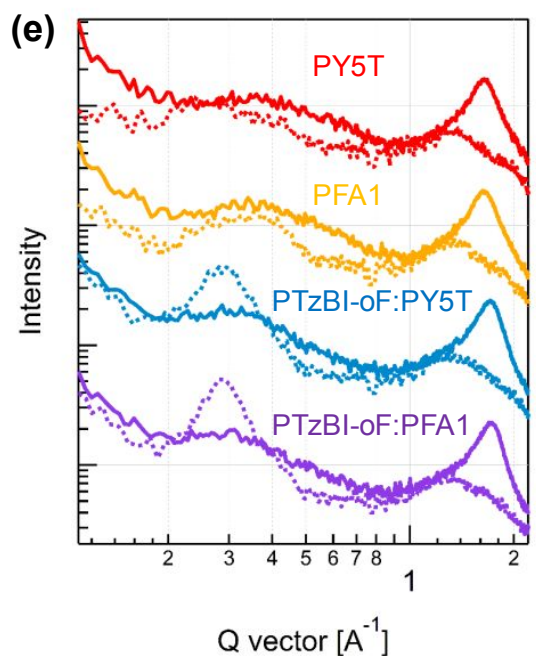

Figure S11. (a-d) GIWAXS 2D images and (e) sector averaged curves in the OOP (solid lines) and IP (dotted lines) directions of pristine films and BHJ films.
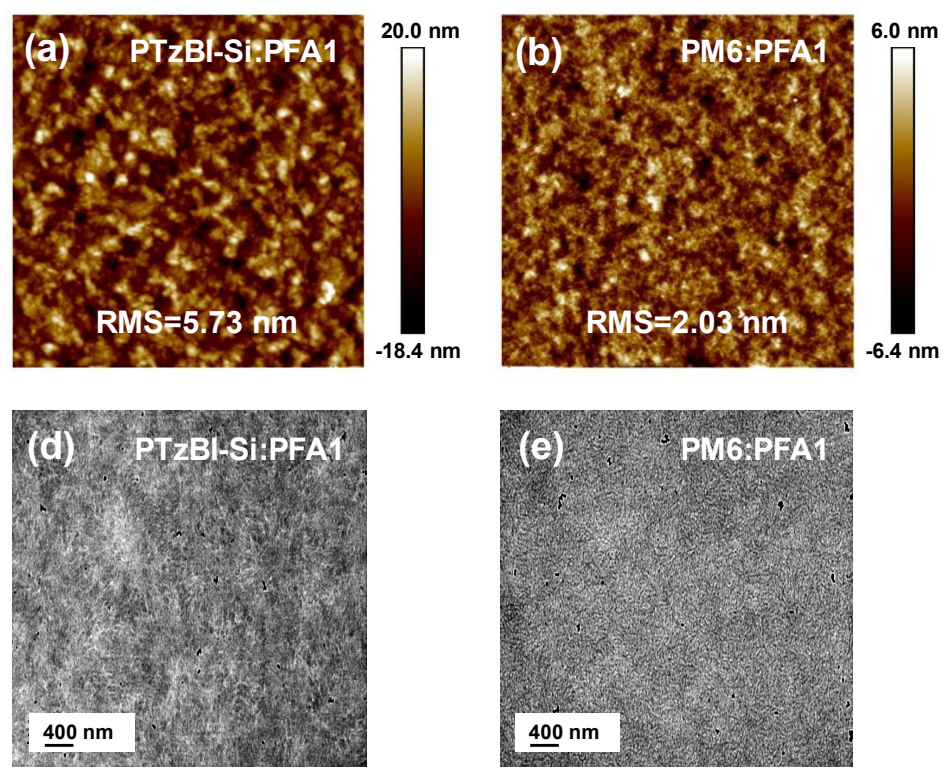
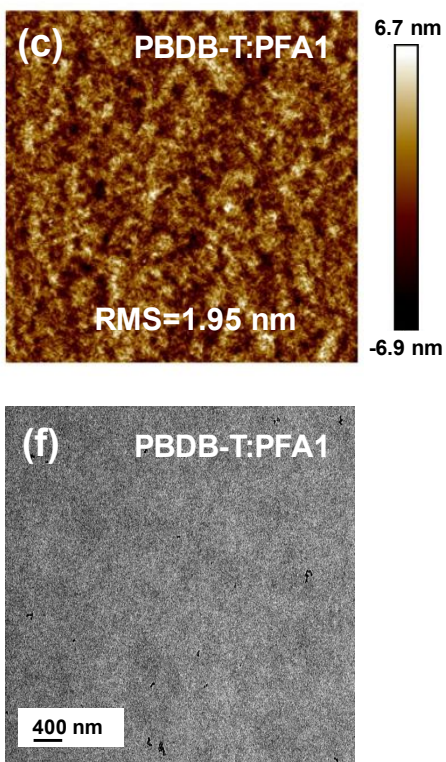

Figure S12. (a, b, c) AFM height images (images size: $5 \mu \mathrm{m} \times 5 \mu \mathrm{m})$ and $(\mathrm{d}, \mathrm{e}, \mathrm{f}) \mathrm{TEM}$ images of the blend films. 


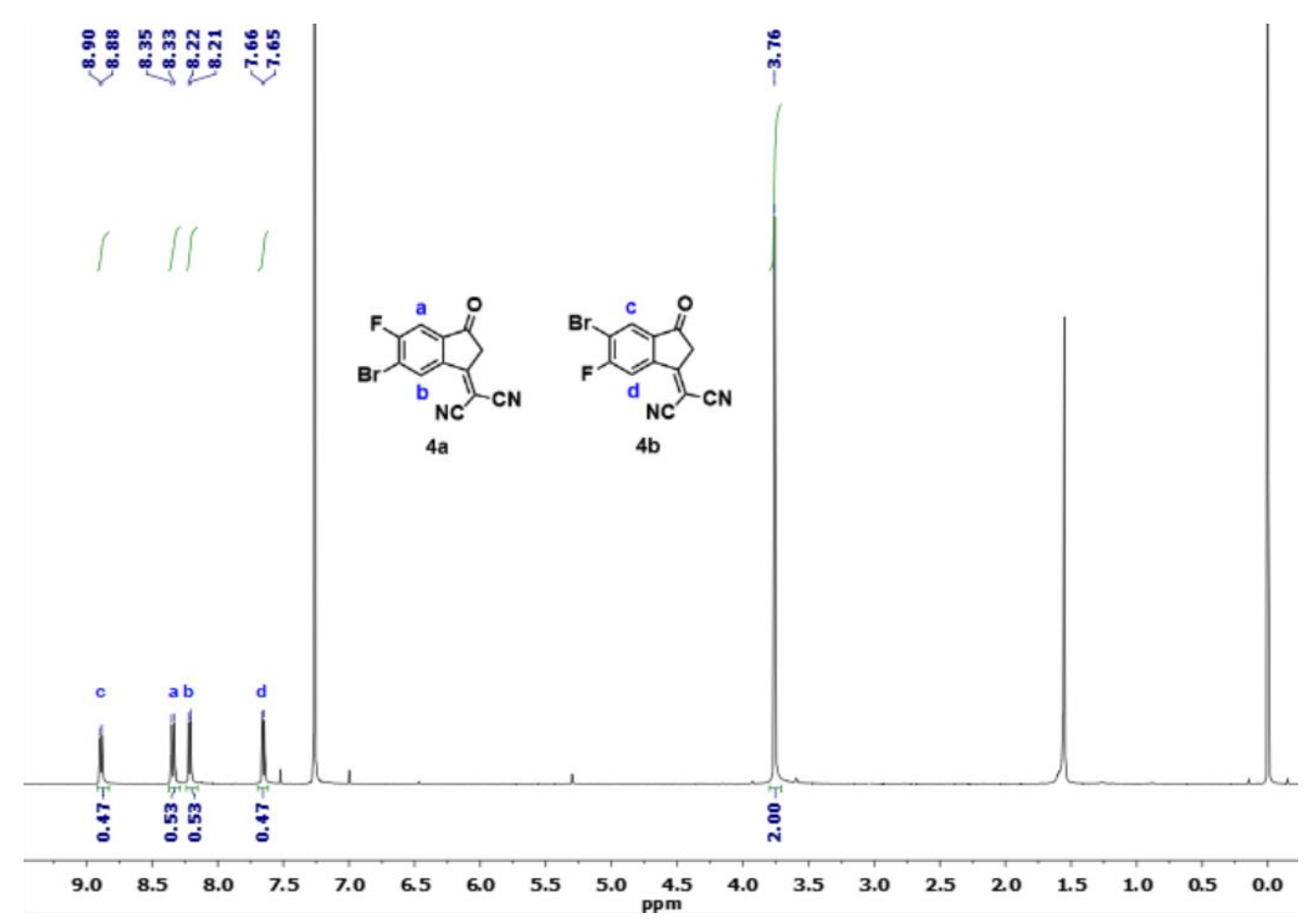

Figure S13. ${ }^{1} \mathrm{H}$ NMR spectrum of $4 \mathrm{a}$ and $4 \mathrm{~b}$.

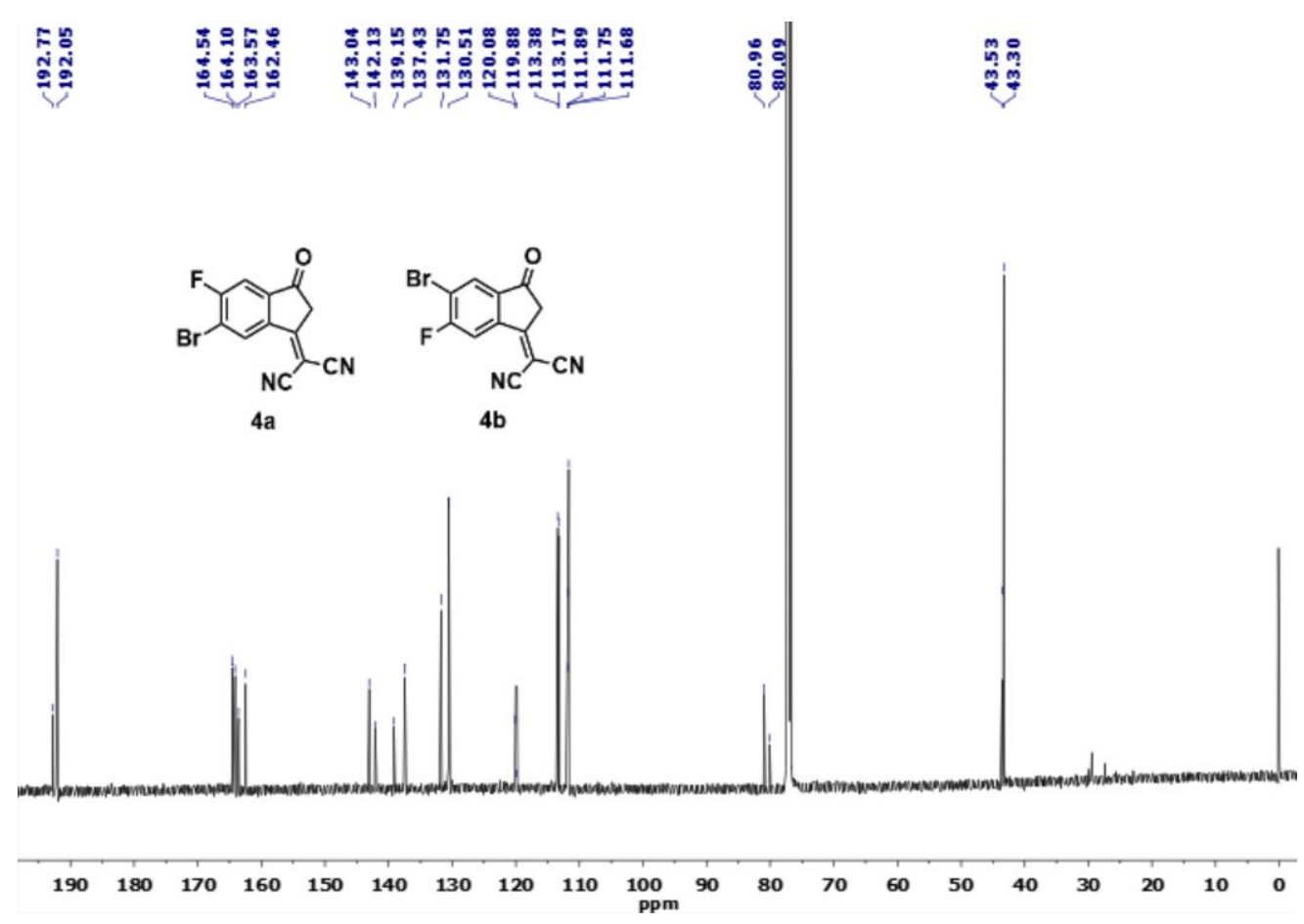

Figure S14. ${ }^{13} \mathrm{C}$ NMR spectrum of $4 \mathrm{a}$ and $4 \mathrm{~b}$. 


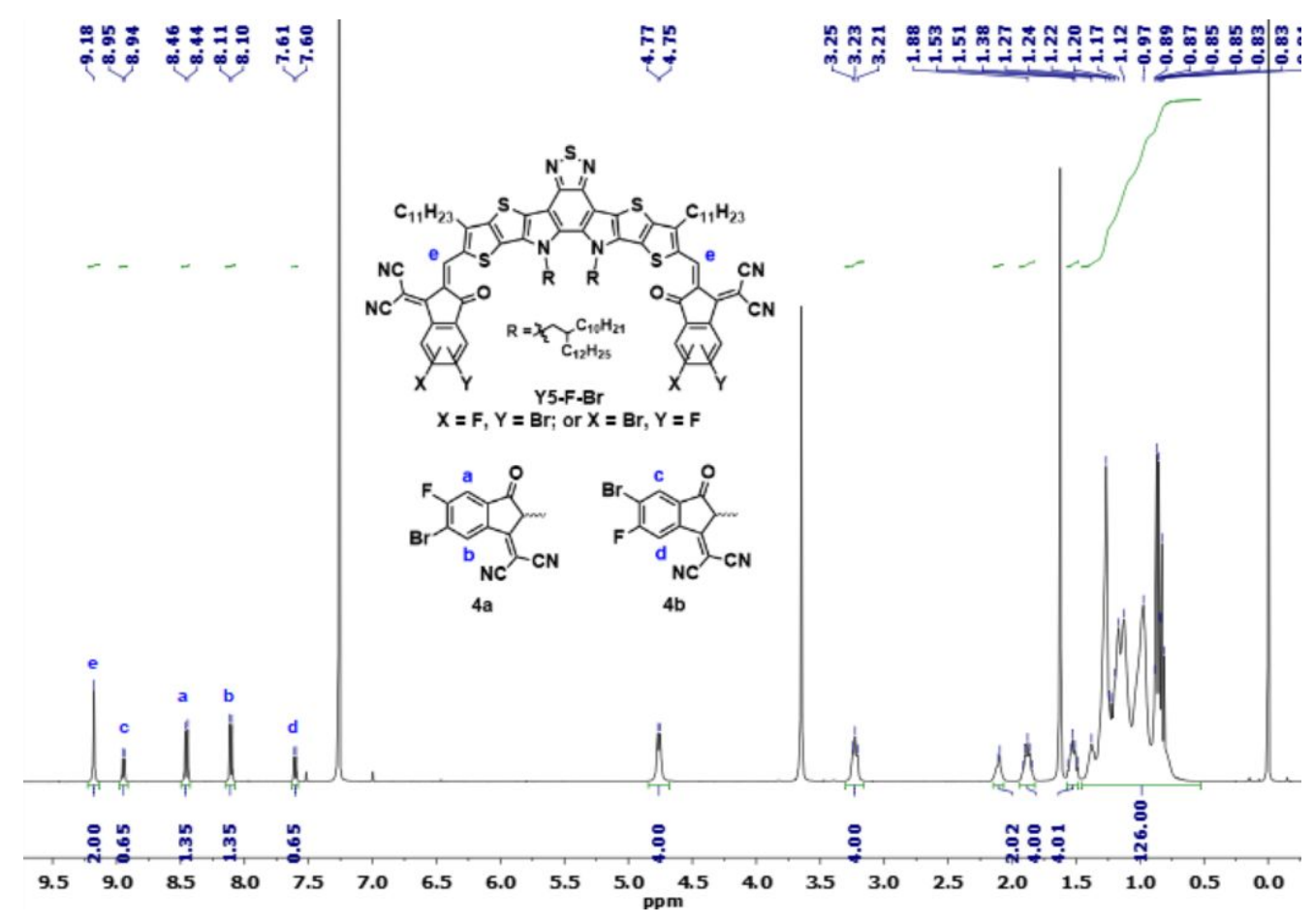

Figure S15. ${ }^{1} \mathrm{H}$ NMR spectrum of Y5-F-Br.

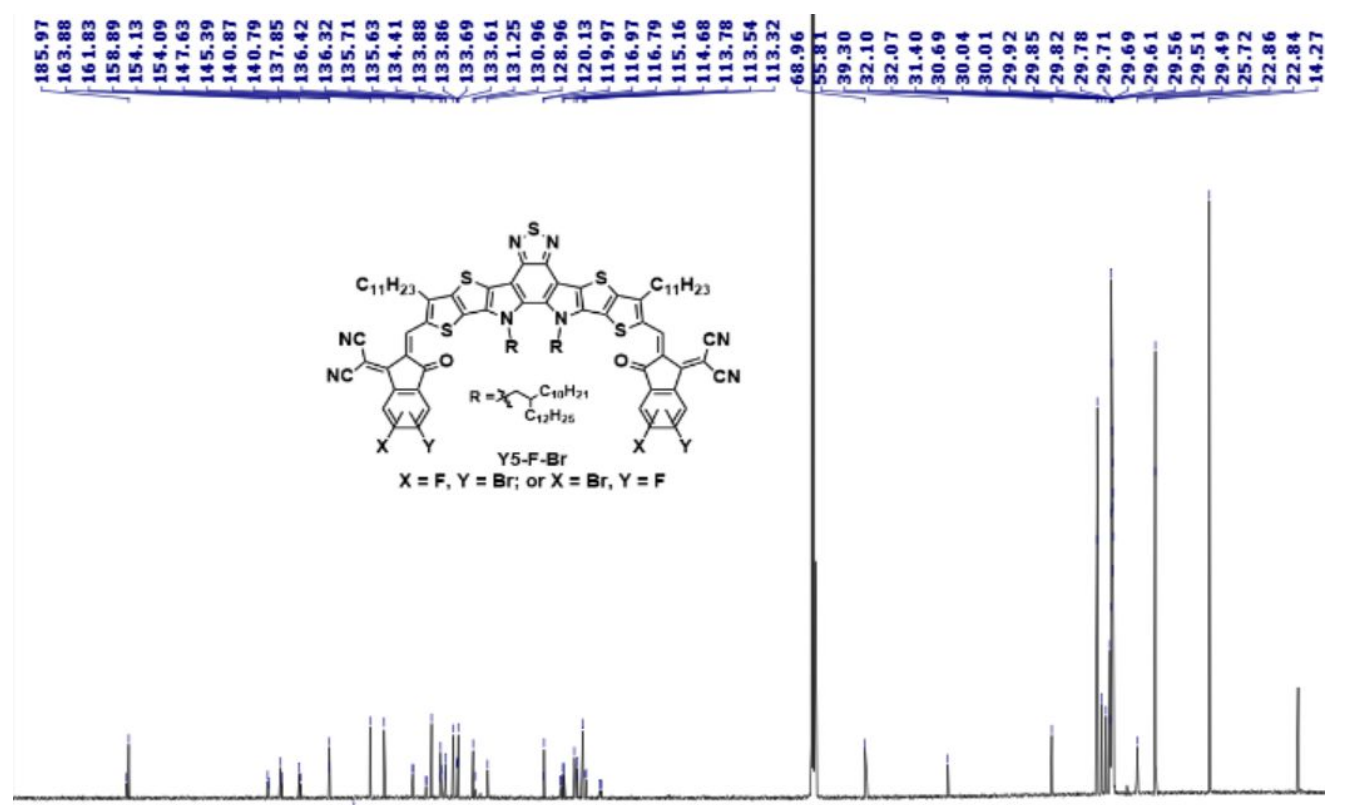

$\begin{array}{lllllllllllllllllllll}200 & 190 & 180 & 170 & 160 & 150 & 140 & 130 & 120 & 110 & \begin{array}{c}100 \\ \mathrm{ppm}\end{array} & 90 & 80 & 70 & 60 & 50 & 40 & 30 & 20 & 10 & 0\end{array}$

Figure S16. ${ }^{13} \mathrm{C}$ NMR spectrum of Y5-F-Br. 


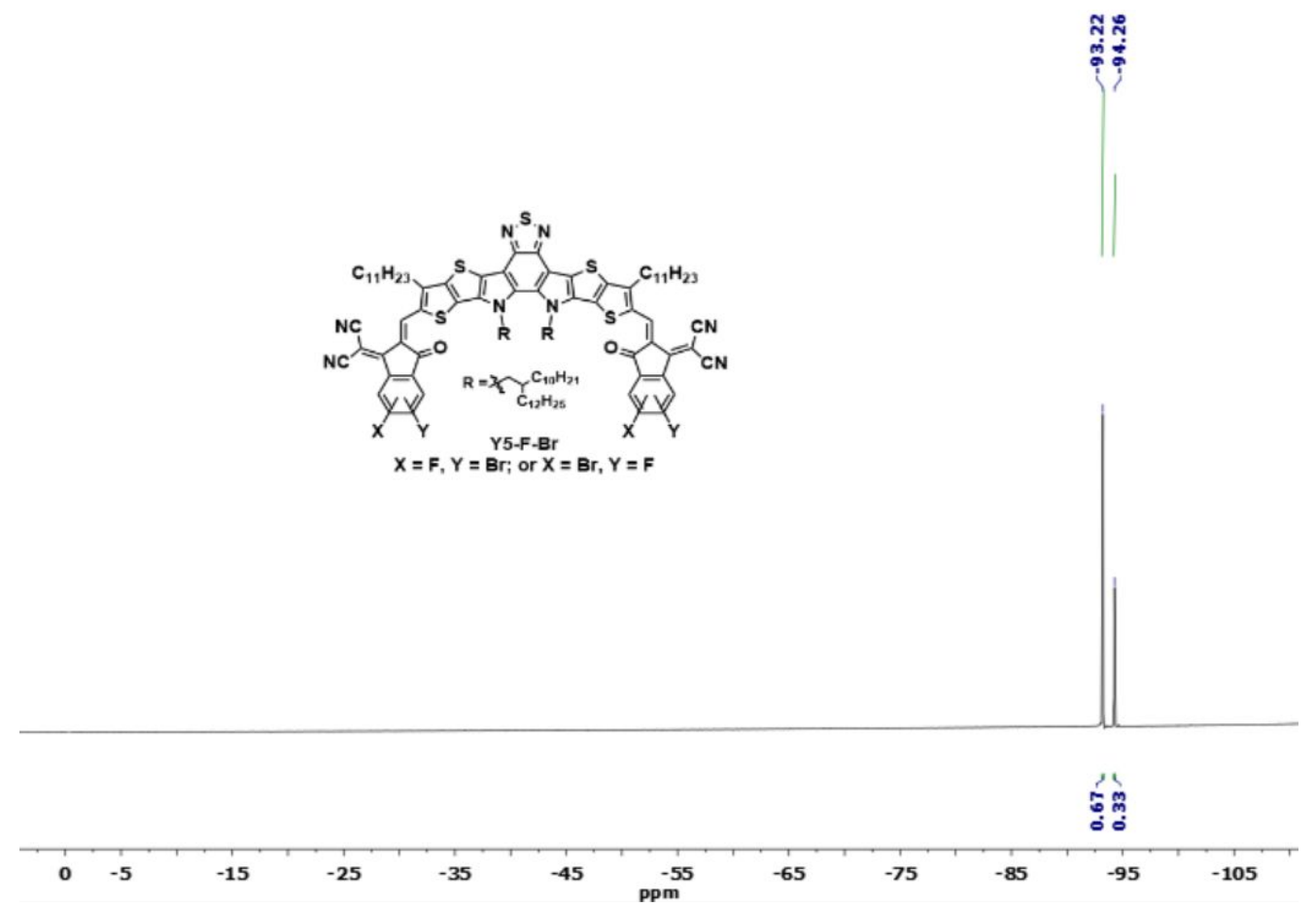

Figure S17. ${ }^{19} \mathrm{~F}$ NMR spectrum of Y5-F-Br. 
Table S1. Optical and electrical properties of polymers.

\begin{tabular}{|c|c|c|c|c|c|c|c|c|}
\hline Polymer & $\begin{array}{l}\lambda_{\max }^{a} \\
(\mathrm{~nm})\end{array}$ & $\begin{array}{c}\varepsilon_{\max }^{\mathrm{a}} \\
\left(\times 10^{5} \mathrm{M}^{-1} \mathrm{~cm}^{-1}\right)\end{array}$ & $\begin{array}{l}\lambda_{\max }^{b} \\
(\mathrm{~nm})\end{array}$ & $\begin{array}{c}\varepsilon_{\max }^{\mathrm{b}} \\
\left(\times 10^{4} \mathrm{~cm}^{-1}\right)\end{array}$ & $\begin{array}{l}\lambda_{\text {onset }} \mathrm{b} \\
(\mathrm{nm})\end{array}$ & $\begin{array}{l}\mathrm{E}_{\mathrm{g}}^{\mathrm{c}} \\
(\mathrm{eV})\end{array}$ & $\begin{array}{l}\mathrm{HOMO}^{\mathrm{d}} \\
\qquad(\mathrm{eV})\end{array}$ & $\begin{array}{l}\mathrm{LUMO}^{\mathrm{d}} \\
(\mathrm{eV})\end{array}$ \\
\hline PTzBI-oF & 625 & 1.7 & 639 & 7.4 & 710 & 1.75 & -5.25 & -3.25 \\
\hline PY5T & 778 & 1.5 & 792 & 8.2 & 852 & 1.46 & -5.71 & -3.76 \\
\hline PFA1 & 800 & 0.7 & 815 & 9.4 & 881 & 1.41 & -5.74 & -3.84 \\
\hline
\end{tabular}

${ }^{a}$ Measured in dilute chloroform solution. ${ }^{b}$ Measured in thin film spin-coated from chloroform solution. ${ }^{\mathrm{c}}$ Calculated by the equation of $1240 / \lambda_{\text {onset. }}{ }^{\mathrm{d}}$ Estimated from cyclic voltammetry measurements.

Table S2. Photovoltaic parameters for PTzBI-oF:PY5T-based all-PSCs processed with/without solvent additive.

\begin{tabular}{cccccc}
\hline Blend & SA & $V_{\mathrm{OC}}$ & $J_{\mathrm{SC}}$ & $\mathrm{FF}$ & PCE \\
& & $(\mathrm{V})$ & $\left(\mathrm{mA} \mathrm{cm}^{-2}\right)$ & $(\%)$ & $(\%)$ \\
\hline & $/$ & 0.90 & 9.72 & 46.78 & 4.09 \\
PTzBI-oF:PY5T & & & & & 4.01 \\
\hline
\end{tabular}


Table S3. Photovoltaic parameters for PTzBI-oF:PFA1-based all-PSCs processed with different solvent additives.

\begin{tabular}{|c|c|c|c|c|c|}
\hline Blend & SA & $\begin{array}{l}V_{\mathrm{OC}} \\
(\mathrm{V})\end{array}$ & $\begin{array}{c}J_{\mathrm{SC}} \\
\left(\mathrm{mA} \mathrm{cm}{ }^{-2}\right)\end{array}$ & $\begin{array}{l}\text { FF } \\
(\%)\end{array}$ & $\begin{array}{l}\text { PCE } \\
(\%)\end{array}$ \\
\hline \multirow{4}{*}{ PTzBI- $o$ F:PI } & I & 0.87 & 23.53 & 64.76 & 13.23 \\
\hline & $0.5 \% \mathrm{DIO}$ & 0.86 & 24.10 & 65.96 & 13.72 \\
\hline & $0.5 \% \mathrm{DBE}$ & 0.87 & 24.60 & 63.05 & 13.43 \\
\hline & $0.5 \% \mathrm{CN}$ & 0.87 & 23.96 & 72.67 & 15.11 \\
\hline
\end{tabular}

Table S4. Photovoltaic parameters for PTzBI-oF:PFA1-based all-PSCs processed with different amount of chloronaphthalene.

\begin{tabular}{|c|c|c|c|c|c|}
\hline Blend & SA & $\begin{array}{l}V_{\mathrm{OC}} \\
(\mathrm{V})\end{array}$ & $\begin{array}{c}J_{\mathrm{SC}} \\
\left(\mathrm{mA} \mathrm{cm}^{-2}\right)\end{array}$ & $\begin{array}{l}\text { FF } \\
(\%)\end{array}$ & $\begin{array}{l}\text { PCE } \\
(\%)\end{array}$ \\
\hline \multirow{4}{*}{ PTzBI-oF:PF } & I & 0.87 & 23.53 & 64.76 & 13.23 \\
\hline & $0.3 \% \mathrm{CN}$ & 0.86 & 23.93 & 68.91 & 14.23 \\
\hline & $0.5 \% \mathrm{CN}$ & 0.87 & 23.96 & 72.67 & 15.11 \\
\hline & $0.7 \% \mathrm{CN}$ & 0.87 & 23.95 & 69.69 & 14.56 \\
\hline
\end{tabular}


Table S5. Photovoltaic parameters for PTzBI-oF:Y5-F-Br-based PSCs.

\begin{tabular}{ccccccc}
\hline Blend & SA & $\begin{array}{c}V_{\mathrm{OC}} \\
(\mathrm{V})\end{array}$ & $\begin{array}{c}J_{\mathrm{SC}} \\
\left(\mathrm{mA} \mathrm{cm}^{-2}\right)\end{array}$ & $\begin{array}{c}\mathrm{FF} \\
(\%)\end{array}$ & $\begin{array}{c}\mathrm{PCE} \\
(\%)\end{array}$ & $\begin{array}{c}J_{\mathrm{SC}, \mathrm{EQE}} \\
\left(\mathrm{mA} \mathrm{cm}^{-2}\right)\end{array}$ \\
\hline \multirow{2}{*}{ PTzBI-oF:PY5T } & $/$ & 0.83 & 25.70 & 69.54 & 14.92 & 24.55 \\
& $0.5 \% \mathrm{CN}$ & 0.82 & 26.15 & 72.60 & 15.66 & 25.01 \\
\hline
\end{tabular}

Table S6. Relative parameters obtained from $J_{\mathrm{ph}}-V_{\mathrm{eff}}, V_{\mathrm{OC}}-\mathrm{P}_{\text {light }}, J_{\mathrm{SC}}-P_{\text {light }}$ and Dark $J-V$ curves.

\begin{tabular}{cccccccc}
\hline & $\mathrm{R}_{\mathrm{s}}$ & $\mathrm{R}_{\mathrm{sh}}$ & $\mathrm{n}$ & $\alpha$ & $J_{\mathrm{sc}}$ & $J_{\text {sat }}$ & $\mathrm{P}(\mathrm{E}, \mathrm{T})$ \\
Acceptor & $\left(\Omega \mathrm{cm}^{2}\right)$ & $\left(\Omega \mathrm{cm}^{2}\right)$ & $\left(V_{\mathrm{OC}}-\mathrm{P}_{\text {light }}\right)$ & $\left(J_{\left.\mathrm{SC}-\mathrm{P}_{\text {light }}\right)}\right.$ & $\left(\mathrm{mA} \mathrm{cm}^{-2}\right)$ & $\left(\mathrm{mA} \mathrm{cm}^{-2}\right)$ & $(\%)$ \\
\hline PY5T & 2.18 & $1.12 \times 10^{5}$ & $1.56 \mathrm{kT} / \mathrm{q}$ & 0.85 & 9.23 & 14.66 & 63.01 \\
& & & & & & & \\
PFA1 & 0.90 & $2.63 \times 10^{5}$ & $1.35 \mathrm{kT} / \mathrm{q}$ & 0.98 & 24.12 & 25.24 & 95.59 \\
\hline
\end{tabular}


Table S7. The contact angles and surface free energy parameters of the PTzBI-oF, PY5T and PFA1 pristine films.

\begin{tabular}{|c|c|c|c|c|}
\hline \multirow{2}{*}{ Film } & \multicolumn{2}{|c|}{ Contact Angle $\left(^{\circ}\right)$} & \multirow{2}{*}{ 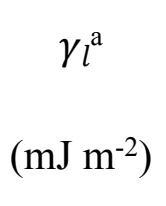 } & \multirow{2}{*}{$\begin{array}{c}\chi_{\text {donor }- \text { acceptor }}{ }^{\mathrm{b}} \\
(\mathrm{K})\end{array}$} \\
\hline & $\mathrm{H}_{2} \mathrm{O}$ & EG & & \\
\hline PTzBI-oF & 103.5 & 72.7 & 38.62 & $\mathrm{NaN}$ \\
\hline PY5T & 100 & 71.1 & 34.13 & $1.38 \times 10^{-1}$ \\
\hline PFA1 & 102.3 & 71.4 & 38.78 & $1.65 \times 10^{-4}$ \\
\hline
\end{tabular}

${ }^{a} \gamma$ represents the surface energy of PTzBI-oF, PY6T and PFA1 pristine films. ${ }^{b}$ FloryHuggins interaction parameter $\chi_{\text {donor-acceptor }}$ estimated from the equation of $\chi_{\text {donor-acceptor }}=K\left(\sqrt{\gamma_{\text {donor }}}-\sqrt{\gamma_{\text {acceptor }}}\right)^{2}, K$ is a constant.

Table S8. Peak fitting parameters of GIWAXS line-cut profiles.

\begin{tabular}{ccccccc}
\hline Sample & peak & Type & $\begin{array}{c}\text { Location } \\
{\left[\mathrm{A}^{-1}\right]}\end{array}$ & $\begin{array}{c}\text { Amplitude } \\
{[\text { a.u. }]}\end{array}$ & $\begin{array}{c}\text { Area } \\
{[\text { a.u. }]}\end{array}$ & $\begin{array}{c}\text { FWHM } \\
{\left[\mathrm{A}^{-1}\right]}\end{array}$ \\
\hline PY5T & 0 & Gauss & 0.25 & 4.42 & 0.44 & 0.094 \\
& 1 & Gauss & 0.36 & 2.50 & 0.47 & 0.175 \\
& & & & & & \\
& 0 & Gauss & 0.25 & 2.74 & 0.26 & 0.089 \\
PFA1 & 1 & Gauss & 0.36 & 7.25 & 1.27 & 0.165 \\
& & & & & 3.03 & 0.096 \\
PTzBI-oF:PY5T & 0 & Gauss & 0.29 & 29.75 & 3.04 & 0.077 \\
\hline
\end{tabular}


Table S9. Photovoltaic parameters for all-PSCs based on PFA1 and three commercial polymer donors.

\begin{tabular}{|c|c|c|c|c|c|c|}
\hline Blend & $\begin{array}{l}\text { Solvent } \\
\text { additive }\end{array}$ & Annealing & $\begin{array}{l}V_{O C} \\
(\mathrm{~V})\end{array}$ & $\begin{array}{c}J_{S C} \\
\left(\mathrm{~mA} \mathrm{~cm}^{-2}\right)\end{array}$ & $\begin{array}{l}F F \\
(\%)\end{array}$ & $\begin{array}{l}\text { PCE } \\
(\%)\end{array}$ \\
\hline PTzBI-Si:PFA1 & $2 \% \mathrm{DBE}$ & $100^{\circ} \mathrm{C} / 10 \mathrm{~min}$ & 0.84 & 21.29 & 66.88 & 11.94 \\
\hline PBDB-T:PFA1 & $1 \% \mathrm{CN}$ & $100^{\circ} \mathrm{C} / 10 \mathrm{~min}$ & 0.83 & 24.26 & 70.18 & 14.20 \\
\hline PM6:PFA1 & $0.5 \% \mathrm{CN}$ & $100^{\circ} \mathrm{C} / 10 \mathrm{~min}$ & 0.90 & 22.41 & 68.10 & 13.75 \\
\hline
\end{tabular}

\section{References}

(1) Jia, T.; Zhang, J.; Zhong, W.; Liang, Y.; Zhang, K.; Dong, S.; Ying, L.; Liu, F.; Wang, X.; Huang, F.; Cao, Y. 14.4\% Efficiency All Polymer Solar Cell with Broad Absorption and Low Energy Loss Enabled by a Novel Polymer Acceptor. Nano Energy 2020, $72,104718$.

(2) Fan, B.; Li, M.; Zhang, D.; Zhong, W.; Ying, L.; Zeng, Z.; An, K,; Huang, Z.; Shi,

L.; Bazan, G. C.; Huang, F.; Cao Y. Tailoring Regioisomeric Structures of $\pi$ Conjugated Polymers Containing Mono-Fluorinated $\pi$-Bridges for Highly Efficient Polymer Solar Cells. ACS Energy Lett. 2020, 5, 2087-2094. 